\title{
LEGAL DESCRIPTION OF THE FACTORING CONTRACT IN ROMANIA
}

\author{
Svitlana Pylypenko', Yuliia Udovenko², Vitalii Cherneha ${ }^{3}$
}

\begin{abstract}
In light of the fact that capital is a major factor in production, the development of entrepreneurial activity becomes impossible without considering the financial market and the resources provided to its subjects. Regardless of the degree of development, any entrepreneurial activity is engaged in direct contact with financial markets, in particular through institutions that act as intermediaries in raising money and services. The development of a solid basis for doing business requires understanding the rules of functioning of the financial system and its mechanisms. Considering the current economic situation, as well as the procedure for granting loans by banks, which is gradually becoming more complicated, while the national and international markets require capital movement, factoring becomes the most accessible instrument and only source of financing, with which the latter increases concurrently with sales. Therefore, the aim of this article is to study the legal nature of the factoring contract in Romania: to identify its regulation object, functions, types, legal features, and other specificities to introduce the positive experience of foreign colleagues to the legislation of Ukraine. Methodology. It is proved that the current legislation concerning the issue of factoring in Ukraine should be improved because in our country the factoring market is still not very common in spite of its rapid development in the world. Moreover, there are no thorough studies on factoring in general and a factoring agreement in particular; some issues on this topic have been considered only in scientific articles. Therefore, the authors refer to the legislation of Romania to determine those features of legal regulation, which have contributed to the rapid and effective development of this institution in this country, and to make appropriate proposals for improving domestic legislation with the use of positive foreign experience. Results. The article suggests a general description of the factoring contract in Romania: the concept of this agreement is revealed; the object of its regulation, as well as implementation of the factoring contract, is determined; its functions and features are described; the parties to the agreement and their legal status are determined. The specificities that have contributed to the rapid enlargement of factoring in Romania are given particular consideration. Practical implication. The factoring agreement as an operating instrument for credit institutions is especially important due to its constant practical applicability that enables to choose the optimal commercial activity both at the national and international levels. Relevance/originality. In Ukraine, given the need for further development of entrepreneurial activity, the issue of increasing total factoring operations is important. The implementation of positive international experience on this issue in domestic legislation is essential for this stage.
\end{abstract}

Key words: factoring, factoring contract, receivables, client, factor, debtor, subrogation, liquidity.

JEL Classification: G17, H68

\section{Introduction}

In light of the fact that capital is a major factor in production, the development of entrepreneurial activity becomes impossible without considering the financial market and the resources provided to its subjects. Regardless of the degree of development, any entrepreneurial activity is engaged in direct contact with financial markets, in particular through institutions that act as intermediaries in raising money and services. The development of a solid basis for doing business requires understanding the rules of functioning of the financial system and its mechanisms. Considering the current economic situation, as well as the fact that the procedure for granting loans by banks is gradually becoming more complicated, while the national and international markets require capital movement, factoring becomes the most accessible instrument and only source of financing, with which the latter increases concurrently with sales. In addition, factoring is the cheapest form of short-term financing. Providing financing without

\footnotetext{
Corresponding author:

${ }^{1}$ National Academy of Internal Affairs, Ukraine.

${ }^{2}$ Vadym Hetman Kyiv National Economic University, Ukraine.

Email: shmatova85@ukr.net

${ }^{3}$ Vadym Hetman Kyiv National Economic University, Ukraine.

Email: vitalii.cherneha@kneu.edu.ua
} 
guarantees and being a complex product of commercial management, the factoring agreement is considered the most optimal economical solution for companies that do not have sufficient financial support, but have a welldesigned business plan (Paraschiv, 2013). Despite the rapid development of this market segment of financial services over the last years in the world, factoring in Ukraine has not yet become sufficiently widespread due to economic instability and rising inflation. Instead, in the neighbouring country of Romania, the factoring market is developing at the fastest pace in Europe.

Therefore, the aim of this article is to study the legal nature of the factoring contract in Romania: to identify its regulation object, functions, types, legal features and other specificities to introduce the positive experience of foreign colleagues to the legislation of Ukraine.

The results of the study are a general description of the factoring contract in Romania, exposed in the article, such as: the concept of this contract is revealed, the object of its regulation, as well as implementation of the factoring contract, are determined, its functions and features are described, the parties to the agreement and their legal status are determined. The specificities that have contributed to the rapid enlargement of factoring in Romania are given particular consideration.

\section{Main material}

In world practice, factoring operations have become widely used for product sales since the $60 \mathrm{~s}$ of the last century. The dynamics of the market for factoring services in the leading countries of the world during the last 7 years is positive, the annual total growth is about $18 \%$.

In Ukraine, for the first time, the possibility of factoring operations was provided for in the Law of Ukraine "On Banks and Banking" as of March 20, 1991 (Pro banky i bankivsku diialnist, 2001); for example, Art. 3 provides for that banks can perform banking transactions to acquire the right to receivables of goods and services, taking credit risk of such receivables and collection of these receivables (factoring). Despite the fact that factoring as an operating instrument for credit institutions is especially important because of possibility to choose the optimal commercial activity both at the national and international levels, in Ukraine it has not yet become sufficiently widespread due to economic instability and inflation.

At the same time, over the past five years, the Romanian factoring market has grown by more than $100 \%$, and in 2015, it was the largest growth in Europe (35\%), up to 3.65 billion euros. The factoring market in Romania began to develop in 1993 through specialized departments of banks, and in 2006, specialized non-bank financial institutions were created. Currently, 15 participants operate in the Romanian factoring market.

In order to protect and represent the interests of the factoring sector and those involved in this activity, in 2011, the Romanian Factoring Association (RFA) was created, which currently has nine members. In April 2012, the RFA signed an agreement on cooperation with the International Factors Association (IFA). It is known that the IFA is the largest association of financial companies in the world, and its members are factoring companies, lenders that provide asset financing, and other institutions that perform financing receivables. At present, the association has more than 375 corporate members.

The cooperation agreement is extremely important as it is aimed at assisting the members of this association by providing information, organizing scientific events to discuss factoring issues, facilitating other activities agreed by the signatories. In addition, the agreement supports the participants in the Romanian market by providing them with the necessary data, access to professional training, and guaranteeing their creditworthiness. Since 2013 , annually the RFA has been studying changes in the key factors of the factoring market. This analysis is based on information provided by members of the association and other non-bank financial institutions.

Moreover, the RFA managed receivables from companies by 14.5 billion EUR, providing the country's economy with significant support.

In the development of the Romanian factoring market, the main role is assigned to banks through their specialized divisions. Meanwhile, non-bank financial institutions also contribute greatly, in particular by ensuring a diversified market for companies of any profile. Now, the Romanian market has high interest from foreign capital to finance the factoring sector, in particular, non-bank financial institutions.

The concept of factoring traces its origin to AngloSaxon law of the XVII century when it played a significant role in the development of international trade, because of contribution to the supply of textiles to the United States of America by England. The specialized literature states, "British industrialists who supplied textiles to British emigrants, penetrating even deeper westward, appreciated the need to find guarantors to provide their exports. Undoubtedly, these were the first factors" (Gavalda, 1978).

Internationally, the factoring contract is regulated by the UNIDROIT International Factoring Convention, adopted on May 28, 1988 (Konventsiia UNIDRUA pro mizhnarodnyi faktorynh), and the United Nations Convention on the Assignment of Receivables in International Trade, adopted on December 12, 2001, in New York (Konventsiia Orhanizatsii Obiednanykh Natsii pro postupku debitorskoi zaborhovanosti $\mathrm{v}$ mizhnarodnii torhivli).

Given the significant role played by factoring in the development of international trade, the importance of establishing uniform rules for a legal framework facilitating international factoring was recognized. Therefore, the UNIDROIT Convention on International Factoring was signed in Ottawa. 
According to article 2 of this Convention, "factoring contract" means a contract concluded between one party (the supplier) and another party (the factor) pursuant to which: a) the supplier may or will assign to the factor receivables arising from contracts of sale of goods (services) made between the supplier and its customers (debtors) other than those for the sale of goods (services) bought primarily for their personal, family or household use; $b$ ) the factor is to perform at least two of the following functions: finance for the supplier, including loans and advance payments; maintenance of accounts (ledgering) relating to the receivables; collection of receivables; protection against default in payment by debtors; c) notice of the assignment of the receivables is to be given to debtors.

In Romanian legislation, the definition of a factoring agreement was first provided in Article 2 letter b) of the Emergency Ordinance no. 10/1997 on easing the financial deadlock and economic losses (Emergency Ordinance no. 10/1997 of 1997 on easing the financial deadlock and economic losses) as a contract between a party called the adherent, supplying goods or providing services, and a bank or a financial institution, called the factor, under which the latter shall finance tracking receivables and safeguard the credit risk, and the adherent assigns to the factor claims arising from the sale of goods or the provision of services to third parties.

This definition was somewhat adjusted according to Article 146 of the Annex to Order no. 1418/1997 of the Secretary of State, Minister of Finance and Governor of the National Bank of Romania (The Secretary of State, Minister of Finance and Governor of National Bank of Romania), adopted on the chart of accounts for banks and the methodological standards for its use. According to the Annex, the factoring is the operation whereby the client called 'the adherent' assigns ownership of receivables (bills) to its commercial bank, called 'the factor', which has an obligation, under contract, to ensure recovery of receivables of the adherent, assuming their risk of default.

Finally, Article 6 of the Law no. 469/2002 on certain measures for strengthening the contractual discipline (Law no. 469/2002 of 2002 on certain measures for strengthening the contractual discipline) defines the factoring contract as a contract between the Party, providing goods or services, called the adherent, and a bank or a financial specialized institution, called the factor, under which the latter shall finance tracking receivables and preserves against credit risks and the adherent assigns to the factor receivables arising from the sale of goods or services to third parties. It should be noted that according to this legal regulation, the factor had to assume three obligations in its relationships with the adherent, without the possibility to choose one of them: financing, monitoring receivables, and safeguarding credit risks.

The mechanism for the implementation of factoring operations can be described as it follows: under the factoring contract, the adherent sends original invoices or certified copies to the factor thereof with the mention that they were sold and that the payment is to be made to the factor; subrogation must be reported to the debtor to pay it by the factor; the factor pays indebtedness to the adherent at face value, less commission either immediately, therefore, before their maturity (old line factoring) or at maturity if the contract was concluded in that form (maturity factoring). In practice, such a system is used for only immediate payment of a percentage of the invoices by the factor, while the remaining should be repaid after the receivable.

In most cases, a framework factoring contract is used that comprises the obligation of the factor to buy and the client to sell all claims or those that meet certain criteria, which the Parts determine, while each claim assignment is entered into a factoring contract separately. It should be noted that the adherent may send a receivable to the factor only partially and repay the rest by himself.

Factoring operations are classified by the following criteria:

1) according to the time of payment of receivables from the adherent by the factor:

a) an 'old line' factoring contract, that is, payment of receivables is made by the factor when receiving bills, so before they reach maturity;

b) a maturity factoring contract, that is, the factor pays claims when it is payable;

c) an agent factoring contract, that is, the factor buys the receivables of the adherent and upon assignment, pays the bills in advance, assuming the risk of default by debtors. The difference is that the adherent undertakes the management of receivables, when receives them in own name and transfers them to the factor;

2 ) according to the right of recourse that the bank can exert over the adherent:

a) a factoring contract with recourse, that is, the adherent takes the debtor's credit risk or refusal to pay the debt; b) a non-recourse factoring contract, that is, the factor pays receivables when receiving the invoices from the adherent;

3 ) according to participants in the factoring operation: a) an internal factoring contract, that is, the factoring operation takes place on the territory of a single country, intervening only one factor;

b) an external factoring contract, that is, an international commercial contract takes place, intervening two factors: the import factor and the export factor (Nemeş, 2013).

The object of the factoring agreement is the receivables, which the factor monitors, finances, and preserves against credit risks, in exchange for which the adherent assigns all its claims on debtors to the factor. In order to become an object of a factoring agreement, the receivable shall be clear and liquid, and it should distinctly specify its maturity or, at least, an opportunity to specify it. Future receivables may also be the object of a factoring agreement.

In view of the risk the factor undertakes, the factoring contract includes a special provision that the adherent is obliged to transfer all invoices, including accounts receivable, to the factor, and the factor can accept only those 
that show a high degree of certainty about their repayment at maturity by the debtors ("exclusivity"). In addition, the factoring agreement includes a requirement of globality, through which the adherent shall transfer all its claims on debtors to the factor. This prevents assigning by adherent to the factor only bad debts, which are difficult to recover and retain only certain receivables. The two requirements are interdependent (Stănciulescu, Nemeş, 2013).

Factoring is a bilateral agreement involving the adherent and the factor. The debtor is a participant of a factoring operation, but is not a Party, although he/she has some concerns in it, what will be discussed later on.

The adherent is a conscientious supplier of goods or provider of services or a contractor, that is, a natural or legal person engaged in a particular type of commercial activity. According to specialized literature, the adherent can be a non-commercial legal entity, recognized by law as having the ability to conduct business (for example, an associations, funds or unions) (Vartolomei, 2006).

While the adherent can be both a natural or legal person engaged in a particular type of commercial activity, and according to some scientists, a non-commercial legal entity, can only be a specialized financial institution or banking company which is a legal entity.

The debtor is a buyer of goods or recipient of services to which he is to pay the equivalent of money, products or services provided.

In terms of the factoring agreement, after the adherent transfers the payment obligation to the factor, the debtor is obliged to pay all the amounts recorded in the invoices only to the factoring company. Payment is made at maturity. In case the debtor refuses to pay, the factor is entitled to submit a claim to the court, and the debtor, in turn, may defend himself by using all the remedies, which he would have applied if the applicant were the client himself. For example, the debtor may object to a prohibition on certain actions, a debt repayment before receiving an appropriate notification or a repayment before the distribution of receivables.

Legal features of the factoring contract are:

1) the contract is mutually binding, as its conclusion entails interdependent obligations borne by both parties. The factor undertakes to provide financing, management of receivables and their preservation against credit risks and the client undertakes to submit ownership on receivables arising from the sale of goods or providing services;

2) the factoring contract is consensual because it is concluded through the mere agreement of the parties.

The written form is a condition required for the transaction. In practice, no bank will conclude a factoring contract other than in writing;

3 ) the factoring contract is onerous as each Part aims to achieve a material benefit. Factoring is essentially onerous; without the price that the factor pays for receivables assigned by the adherent a factoring contract does not exist;
4) the factoring contract is continuing because it runs over time;

5) the factoring contract has personal character, according to the doctrine recognized by the scientific majority, because in order to conclude it, the adherent should possess characteristics, such as professional competence, customer stability, respectability, credibility. Some authors doubt this feature because the decision of the factor to refund is influenced by monetary issues and less by the personal characteristics of Parties involved in the factoring mechanism (Stănciulescu, Nemeş, 2013);

6) the agreement is a contract of adhesion because the factor imposes contractual terms. In practice, he can select debtors by himself and deny the assumption of doubtful debts of the adherent;

7) the agreement is an ancillary contract because it determines the relationship between the adherent and the debtor, arising from receivables assigned to the factor; 8) this is a commutative contract because the Parties know their obligations under this agreement from the moment of conclusion. According to Romanian legislation, the factoring contract can be random in case of the factoring contract without recourse, that is, the factor bears the risk of insolvency of the debtor;

9) the contract is complex because it includes an assignment of debt, a subrogation, additional obligations for the factor, such as monitoring of accounts, their keeping, taking credit risk and financing the adherent.

A special condition of validity of the factoring contract consists of the material delivery of invoices by the adherent to the factor.

The essential functions of the factoring contract are:

1) a function of financing, also called a liquidity function.

Under the factoring contract, the factor provides the client with financing services without any additional guarantees; the guarantee is the assignment of all accounts. So the factor, subject to acceptance receivable from the adherent, is obliged to provide the latter with the necessary liquidity, profits from which he gets even before maturity. It should be emphasized that this type of financing is only for a period of 90 to 120 days, and in exceptional cases for 180 days;

2) a service function or management function. When executing a factoring contract, depending on the type of factoring, the factor can provide the adherent with an integrated package of services, which includes: assessing the creditworthiness of the debtors; accounting of debtors with all necessary data on receivables; monitoring of debtor creditworthiness; responsibility for the invoices presented; responsibility for collecting receivables; providing explanations on debt liquidation; providing explanations on accounting and financial debt management; conducting consultations on taxation issues during the implementation of factoring operations, etc.

This function is of particular importance in factoring since it enables the client to avoid spending additional 
costs and time and focus exclusively on his work on the manufacture (supply) of goods or services.

3) a function of credit risk taking. In accordance with this function, the factor takes credit risk after a preliminary examination of the debtor's creditworthiness, that is, his ability to pay off in full and in a timely manner. This means that after the concluding the factoring contract, the factor shall not make a recourse claim to the adherent in case of debtor bankruptcy or delayed payment (Petre, 2007).

Therefore, a comprehensive description of the factoring agreement in Romania enables to single out the features that contributed to the rapid development of factoring in this country. Under challenging economic conditions, the factoring contract is a solution for companies to focus on their commercial activities of manufacturing and purchasing goods or supply of services while maintaining liquidity without having to give guarantees. Another advantage of the factoring contract is protection against the risk of indebtedness of borrowers, buyers of goods or recipients of services provided. Finally, the growing interest of companies for the factoring contract is caused by the possibility to use the experience of banks in assessing the creditworthiness of adherents, in the management and administration of receivables.

On the other hand, factoring is interesting also for the members of the Romanian Factoring Association because it enables them to manage liquidity for a fee, which is higher than the interest rate applied to the loan in the credit market. Banks and specialized non-bank financial institutions concluding factoring contracts, in turn, use all guarantees and privileges of companies manufacturing (supplying) goods or providing services.

\section{Conclusions}

To sum up, the factoring contract is interesting due to the specific provisions: the requirement of exclusivity clause and the requirement of globality. The adherent is obliged to assign all his receivables to the factor, while the latter may accept only that he considers safe in terms of their payment at maturity.

For the development of the factoring market in our country, in the factoring contracts, the list of services provided by banks and other financial institutions should be extended to include such services as:

- accounting of sales, inventory, management of monetary assets;

- providing the adherent with information about the financial and economic status of customers;

- providing the adherent with statistical data concerning the main consumers of the product that he produces (supplies) and its total sale on the market, etc.

Thereby, the factoring company will become not only as a credit institution for the adherent but also the one to provide with banking, insurance, accounting services as well as important commercial information. This will greatly save time and money of the manufacturer (supplier) of the goods and will help him focus solely on his core business.

\section{References:}

Paraschiv, S. M. (2013). Factoring agreement - instrument for credit institutions. International Journal of Juridical Sciences, 4, 138-142.

Pro banky i bankivsku diialnist (2001). [On banks and banking: official bulletin of Ukraine] (Law of Ukraine no. 2121-III of December 7, 2000). Ofitsiynyi visnyk Ukrainy, 1-2(1), 1. (in Ukrainian)

Gavalda, C. (1978). Encyclopédie Juridique, Paris: Dalloz. Retrieved from: https://www.editions-dalloz.fr/ encyclopedie.html? cat $=123$

Konventsiia UNIDRUA pro mizhnarodnyi faktorynh [UNIDROIT Convention on International Factoring] (International Document of May 28, 1988). Retrieved from: http://zakon.rada.gov.ua/laws/show/995_210 (in Ukrainian)

Konventsiia Orhanizatsii Obiednanykh Natsii pro postupku debitorskoi zaborhovanosti v mizhnarodnii torhivli [United Nations Convention on assigning account receivables in international trade] (International Document of December 12, 2001). Retrieved from: http://zakon.rada.gov.ua/laws/show/995_a37 (in Ukrainian)

Emergency Ordinance no. 10/1997 of 1997 on easing the financial deadlock and economic losses. Official Gazette, 72. (April 22, 1997). Retrieved from: http://cis01.central.ucv.ro/revistadestiintepolitice/files/numarul52_2016/3.pdf The Secretary of State, Minister of Finance and Governor of National Bank of Romania (N.B.R.) (August 8, 1997). Order no. 1418/1997 on the chart of accounts for banks and the methodological standards for its use. Official Gazette, 189. Retrieved from: http://cis01.central.ucv.ro/revistadestiintepolitice/files/numarul52_2016/3.pdf

Law no. 469/2002 of 2002 on certain measures for strengthening the contractual discipline. Official Gazette, 529. (July 19, 2002). Retrieved from: http://cis01.central.ucv.ro/revistadestiintepolitice/files/numarul52_2016/3.pdf

Nemeş, V. (2013). Dreptul contractelor civile şi comerciale în reglementarea noului Cod civil [The right to civil and commercial contracts in the regulation of the new Civil Code]. Bucharest: Hamangiu Publishing House.

Stănciulescu, L., Nemeş, V. (2013). Dreptul contractelor civile şi comerciale în reglementarea noului Cod civil [Law regulation of civil and commercial contracts in the new Civil Code]. Bucharest: Hamangiu Publishing House. Vartolomei, B. (2006). Contractul de factoring [The factoring contract]. Bucharest: Lumina Lex Publishing House. Petre, C. (2007). Factoringul, o alternativă modernă de finanțare a întreprinderilor europene [Factoring, a modern alternative to financing European businesses]. EIRP Proceedings, vol. 2. 